\title{
Characteristics of lightweight concrete with different admixtures
}

\author{
Ahmed Fikry ${ }^{1, *}$, Ata El-kareim Shoeib ${ }^{1}$, Anwar Mahmoud ${ }^{2}$, Mohamed H.Agamy ${ }^{1}$ \\ ${ }^{1}$ Faculty of Engineering, Helwan University, Cairo, Egypt \\ ${ }^{2}$ Housing and Building National Research Center, Cairo, Egypt \\ * Email: Dranwarm79@gmail.com
}

\begin{abstract}
Lightweight concrete (LWC) is the most needed material to be used in many applications due to its low density, accepted compression strength, and high thermal properties. This paper study the effect of using lightweight concrete in structural elements using three experimental variables such as (admixtures content, cement content and w/c ratio). For twenty-five different mix trial with different admixtures was used. The slump loss, slump flow, compaction factor, compressive strength at the ages of $7,14,28$, and 56 days and tensile strength at the age of 28 days were obtained. Based on the results the slump ranged from 70 to $140 \mathrm{~mm}$. Moreover, the average slump loss was as same as the average slump loss for the normal concrete(NC). Further, the average compressive strength of the lightweight plain concrete mixtures fluctuated from 70 to $75 \%$ of the compressive strength of normal weight concrete and using admixture improved this ratio. By using mineral admixtures, the compressive strength improved to 90 to $95 \%$ of the normal concrete compressive strength.
\end{abstract}

\section{KEYWORDS}

Lightweight element; mineral admixture; Compressive strength; Tensile strength.

\section{INTRODUCTION}

Structural lightweight concrete is expected to produce accepted compressive strength and high durability with low density [1,2]. The elastic modulus of elasticity of lightweight concrete is lower than that of normal weight concrete. Creep and shrinkage for the lightweight concrete are slightly higher than those of the equivalent normal weight concrete, and this should be taken into account when scheming the structure $[3,4]$. The lightweight aggregates such as (Lightweight Expanded Clay Aggregate (LECA) - Crushed glass - Perlite - Vermiculite Crushed brick), were the main aggregates used to produce a lightweight concrete. Frequently, LECA and vermiculite were used as coarse aggregates to produce lightweight concrete over the last five decades [5,6,7]. Using crushed glass is an innovative technique of producing lightweight concrete according to American Concrete Institute "ACI-130-A Materials for Concrete".[8] Also, the utilization of crushed glass with other quality supplementary cementing materials such as: silica fume, fly ash, and Nano silica $\left(\mathrm{SiO}_{2}\right)$ can provide high compressive strength $[9,10]$. Using these aggregates increased the compressive strength leading to get structural elements with less cross sections. Moreover, it increases the life expectancy for the 
lightweight concrete. In addition to, it enhances the workability and segregation resistance at fresh state. Also, it enhances the durability and mechanical characteristics in the hardened state. [11, 12, 13].

\section{EXPERIMENTAL PROGRAM}

This paper concentrated on the experimental investigation of the fresh and hardened characteristics of lightweight concrete mixes. Twenty-five concrete mixtures were designed. Three parameters were studied: cement content change from 250 to 450 $\mathrm{kg} / \mathrm{m}^{3}$, water (w) to cement (c) ratio (w/c) change from 0.3 to 0.5 and admixtures content. Mixtures tested for slump flow, slump loss, compaction factor and the compressive strength at different ages $7,14,28$, and 56 days.

\subsection{Materials}

Portland cement type I (CEMI $42.5 \mathrm{~N}$ ) produced by Helwan Cement Company achieving the requirement of E.S.S 4756/1/2013 and E.N 197-1/2011 was used in all mixtures. The coarse lightweight aggregate used in this study was local crushed glass with a maximum nominal size $19 \mathrm{~mm}$. The physical characteristics of the used crushed glass are shown in tables (1) and (2). Shape and size are shown in Fig.1: The physical characteristics, shape and size meeting the requirement of (ACI-130-A Materials for Concrete".) [8]. The coarse aggregate to produce normal concrete was local dolomite. Natural sand from Helwan was used as the fine aggregate. Fly ash complying with chemical and physical requirements of standard specification was used. The used micro silica (silica fume) is a product of SIKA company for chemical materials. The used Nano silica is a product of Nanotech Egypt for Nanomaterials with average particles size around 0.001 micrometers. Sika viscocrete 3425 was used as viscosity enhancing agent (VEA). It contains a polycarboxylic-based copolymer with modified cellulose product to accomplish the dual action effect of high-range water reducer and viscosity-modifying admixture.

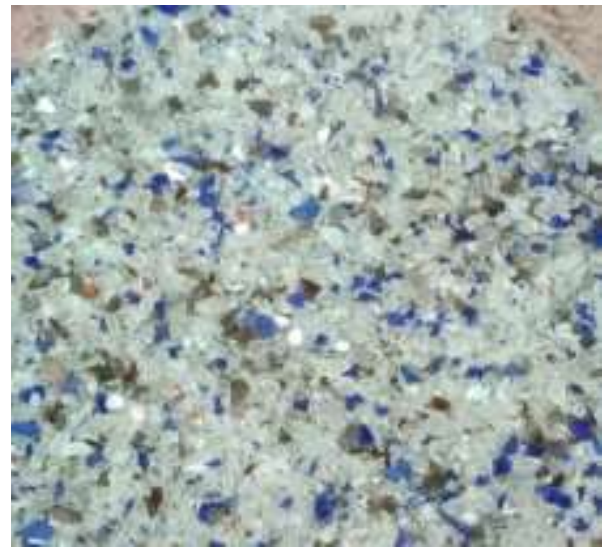

Size range 4.75 to $13 \mathrm{~mm}$

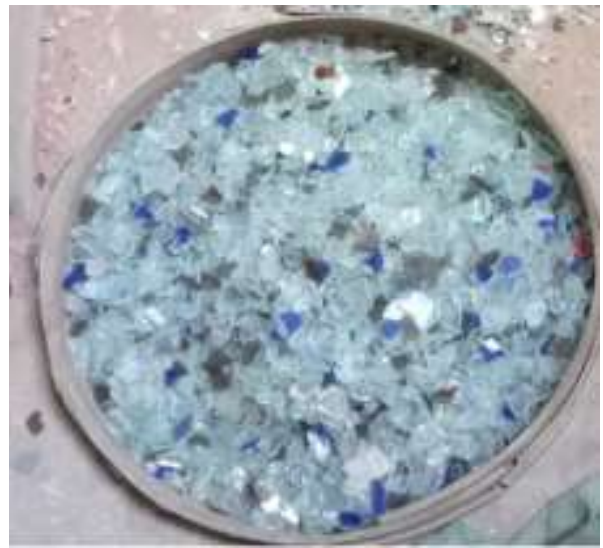

Size range 13 to $19 \mathrm{~mm}$

Fig.1: Size and shape of the crushed glass 
Table 1: The physical characteristics of crushed glass

\begin{tabular}{|c|c|c|c|}
\hline Description & $\begin{array}{c}\text { 24 h water } \\
\text { absorption: } \%\end{array}$ & Specific gravity & $\begin{array}{c}\text { Unit weight } \\
\mathbf{k g} / \mathbf{m}^{\mathbf{3}}\end{array}$ \\
\hline Crushed glass & 16.5 & 1.9 & 1080 \\
\hline
\end{tabular}

Table 2: crushed glass Sieve analysis

\begin{tabular}{|c|c|c|c|c|c|}
\hline Sieve size (mm) & $\mathbf{1 9}$ & $\mathbf{1 6}$ & $\mathbf{9 . 5}$ & $\mathbf{4 . 7 5}$ & $\mathbf{2 . 3 6}$ \\
\hline $\boldsymbol{\%}$ & 100 & 94 & 73 & 29 & 8 \\
\hline
\end{tabular}

\subsection{Mix Design}

All mixtures unit weight did not exceed $2000 \mathrm{~kg} / \mathrm{m}^{3}$, therefore, they were considered lightweight concrete. The mixes were designed according to Standard Practice for selecting characteristics of structural lightweight concrete (ACI 211.2). Table 3 shows the materials quantities for each mix. According to Mix ID: NC, LWC, FA, NS, and SF pointed to normal concrete, lightweight concrete, fly ash, Nano silica and silica fume respectively. Besides, the number signified the ratio of admixtures in the mix design. 
Table 3: Concrete Mix Proportions

\begin{tabular}{|c|c|c|c|c|c|c|c|c|c|c|c|c|}
\hline \multirow[t]{2}{*}{ Group } & \multirow{2}{*}{$\begin{array}{l}\text { Mix } \\
\text { No. }\end{array}$} & \multirow[t]{2}{*}{ Mix Code } & \multirow[t]{2}{*}{$\mathrm{W} / \mathrm{C}$} & \multicolumn{8}{|c|}{ Concrete Ingredients $\left(\mathrm{Kg} / \mathrm{m}^{3}\right)$} & \multirow{2}{*}{$\begin{array}{l}\text { Density } \\
\mathrm{Kg} / \mathrm{m}^{3}\end{array}$} \\
\hline & & & & Cement & Water & $\begin{array}{l}\text { Fine } \\
\text { Agg. }\end{array}$ & $\begin{array}{l}\text { Coarse } \\
\text { Agg. }\end{array}$ & $\begin{array}{l}\text { Fly } \\
\text { Ash }\end{array}$ & $\begin{array}{l}\text { Nano } \\
\text { Silica }\end{array}$ & $\begin{array}{l}\text { Silica } \\
\text { Fume }\end{array}$ & VEA & \\
\hline \multirow{5}{*}{ G A } & 1 & NCO & \multirow{5}{*}{0.3} & \multirow{5}{*}{450} & \multirow{5}{*}{135} & \multirow{5}{*}{500} & 1190 & 0 & 0 & 0 & \multirow{5}{*}{2} & 2277 \\
\hline & 2 & LWCO & & & & & 800 & 0 & 0 & 0 & & 1887 \\
\hline & 3 & LWCFA7.5 & & & & & 800 & 33 & 0 & 0 & & 1920 \\
\hline & 4 & LWCNS2.5 & & & & & 800 & 0 & 11 & 0 & & 1898 \\
\hline & 5 & LWCSF7.5 & & & & & 800 & 0 & 0 & 33 & & 1920 \\
\hline \multirow{5}{*}{ G B } & 6 & NC1 & \multirow{5}{*}{0.4} & \multirow{5}{*}{350} & \multirow{5}{*}{140} & \multirow{5}{*}{500} & 1190 & 0 & 0 & 0 & \multirow{5}{*}{1.5} & 2231.5 \\
\hline & 7 & LWC1 & & & & & 800 & 0 & 0 & 0 & & 1814.5 \\
\hline & 8 & LWCFA10 & & & & & 800 & 40 & 0 & 0 & & 1881.5 \\
\hline & 9 & LWCNS2 & & & & & 800 & 0 & 8 & 0 & & 1849.5 \\
\hline & 10 & LWCSF10 & & & & & 800 & 0 & 0 & 40 & & 1881.5 \\
\hline \multirow{5}{*}{ G C } & 11 & $\mathrm{NC2}$ & \multirow{5}{*}{0.4} & \multirow{5}{*}{350} & \multirow{5}{*}{140} & \multirow{5}{*}{500} & 1190 & 0 & 0 & 0 & \multirow{5}{*}{1} & 2181 \\
\hline & 12 & LWC2 & & & & & 800 & 0 & 0 & 0 & & 1791 \\
\hline & 13 & LWCFA15 & & & & & 800 & 52 & 0 & 0 & & 1843 \\
\hline & 14 & LWCNS1.5 & & & & & 800 & 0 & 5 & 0 & & 1796 \\
\hline & 15 & LWCSF15 & & & & & 800 & 0 & 0 & 52 & & 1843 \\
\hline \multirow{5}{*}{ G D } & 16 & NC3 & \multirow{5}{*}{0.45} & \multirow{5}{*}{300} & \multirow{5}{*}{135} & \multirow{5}{*}{500} & 1190 & 0 & 0 & 0 & & 2125.5 \\
\hline & 17 & LWC3 & & & & & 800 & 0 & 0 & 0 & & 1735.5 \\
\hline & 18 & LWCFA20 & & & & & 800 & 60 & 0 & 0 & 0.5 & 1795.5 \\
\hline & 19 & LWCNS1 & & & & & 800 & 0 & 3 & 0 & & 1738.5 \\
\hline & 20 & LWCSF20 & & & & & 800 & 0 & 0 & 60 & & 1795.5 \\
\hline & 21 & NC4 & & & & & 1190 & 0 & 0 & 0 & & 2065 \\
\hline & 22 & LWC4 & & & & & 800 & 0 & 0 & 0 & & 1675 \\
\hline GE & 23 & LWCFA30 & 0.5 & 250 & 125 & 500 & 800 & 60 & 0 & 0 & 0 & 1735 \\
\hline & 24 & LWCNS & & & & & 800 & 0 & 2 & 0 & & 1677 \\
\hline & 25 & LWCSF20 & & & & & 800 & 0 & 0 & 60 & & 1735 \\
\hline
\end{tabular}

\subsection{Test Specimens}

A standard cubic specimens with dimensions $(15 \times 15 \times 15 \mathrm{~cm})$ were used for compression test of concrete at ages 7,14,28 and 56 days, as shown in Fig.2.

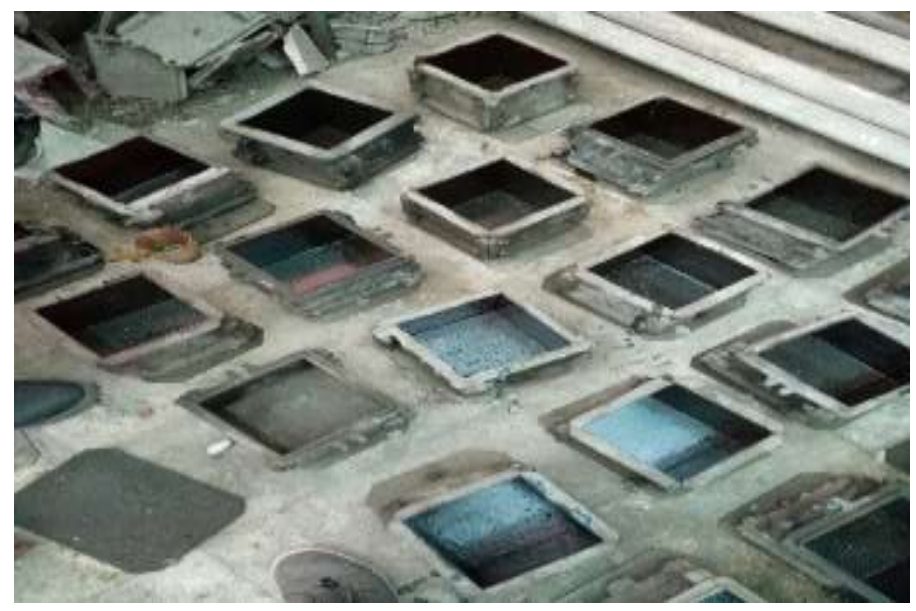

Fig.2: concrete specimens molds 


\section{RESULTS \& DISSCUSION}

The results obtained for the fresh concrete and hardened concrete properties are shown in table 4.

Table 4: Fresh and Hardened Concrete Properties

\begin{tabular}{|c|c|c|c|c|c|}
\hline Group & $\begin{array}{l}\text { Mix } \\
\text { No. }\end{array}$ & Mix Code & Slump (mm) & $\begin{array}{l}\text { Compaction } \\
\text { Factor }\end{array}$ & $\begin{array}{c}\text { Compressive } \\
\text { strength } \mathrm{kg} / \mathrm{cm}^{2}\end{array}$ \\
\hline \multirow{5}{*}{ G A } & 1 & $\mathrm{NCO}$ & 85 & 0.98 & 275 \\
\hline & 2 & LWCO & 73 & 0.96 & 220 \\
\hline & 3 & LWCFA7.5 & 77 & 0.95 & 217 \\
\hline & 4 & LWCNS2.5 & 72 & 0.94 & 265 \\
\hline & 5 & LWCSF7.5 & 75 & 0.96 & 220 \\
\hline \multirow{5}{*}{ G B } & 6 & NC1 & 92 & 0.96 & 270 \\
\hline & 7 & LWC1 & 83 & 0.94 & 215 \\
\hline & 8 & LWCFA10 & 88 & 0.95 & 224 \\
\hline & 9 & LWCNS2 & 89 & 0.93 & 260 \\
\hline & 10 & LWCSF10 & 90 & 0.93 & 230 \\
\hline \multirow{5}{*}{ G C } & 11 & NC2 & 105 & 0.95 & 266 \\
\hline & 12 & LWC2 & 97 & 0.91 & 211 \\
\hline & 13 & LWCFA15 & 100 & 0.93 & 231 \\
\hline & 14 & LWCNS1.5 & 101 & 0.91 & 254 \\
\hline & 15 & LWCSF15 & 100 & 0.91 & 239 \\
\hline \multirow{5}{*}{ G D } & 16 & NC3 & 112 & 0.93 & 260 \\
\hline & 17 & LWC3 & 106 & 0.89 & 207 \\
\hline & 18 & LWCFA20 & 109 & 0.90 & 235 \\
\hline & 19 & LWCNS1 & 109 & 0.9 & 248 \\
\hline & 20 & LWCSF20 & 107 & 0.9 & 243 \\
\hline \multirow{5}{*}{ G E } & 21 & NC4 & 120 & 0.91 & 255 \\
\hline & 22 & LWC4 & 113 & 0.86 & 200 \\
\hline & 23 & LWCFA30 & 116 & 0.88 & 239 \\
\hline & 24 & LWCNS0.75 & 117 & 0.89 & 240 \\
\hline & 25 & LWCSF20 & 114 & 0.88 & 248 \\
\hline
\end{tabular}

\subsection{Fresh Properties of lightweight concrete}

According to ES: 1658-2/2008 [14] immediately after mixing, the value of slump and slump loss were determined. Compaction factor test was carried out according to (B.S) No 1881-115/1983. The slump flow test was used to evaluate the carried out e deformability and flowability of lightweight concrete in the absence of obstruction as shown in Fig.3: The slump value was recorded every 15 minutes after the end of mixing. 

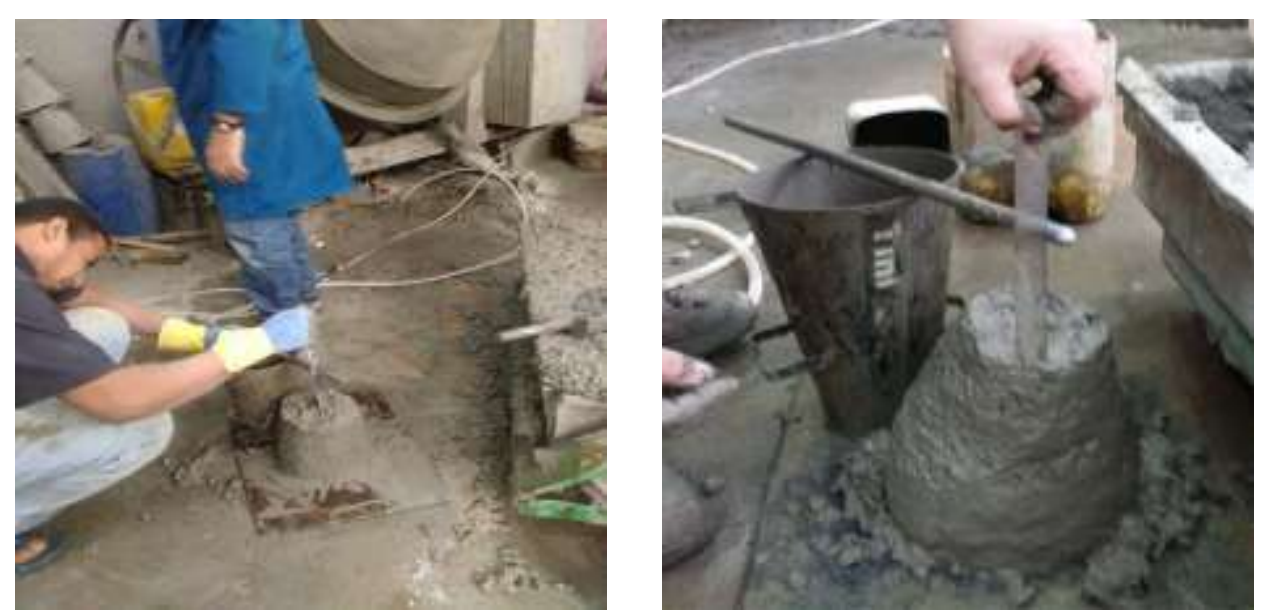

Fig.3: Slump after 30 minutes

\subsubsection{Slump}

Slump flow and slump loss results for the LWC mixtures due to cement content and w/c ratio as same as the slump flow and slump loss for the normal concrete as shown in Fig.4, Fig.5, Fig.6, Fig.7, Fig.8, respectively. For the lightweight concrete mixtures, the cement content and w/c ratio are the main influences of slump loss optimization as shown in Fig.9.

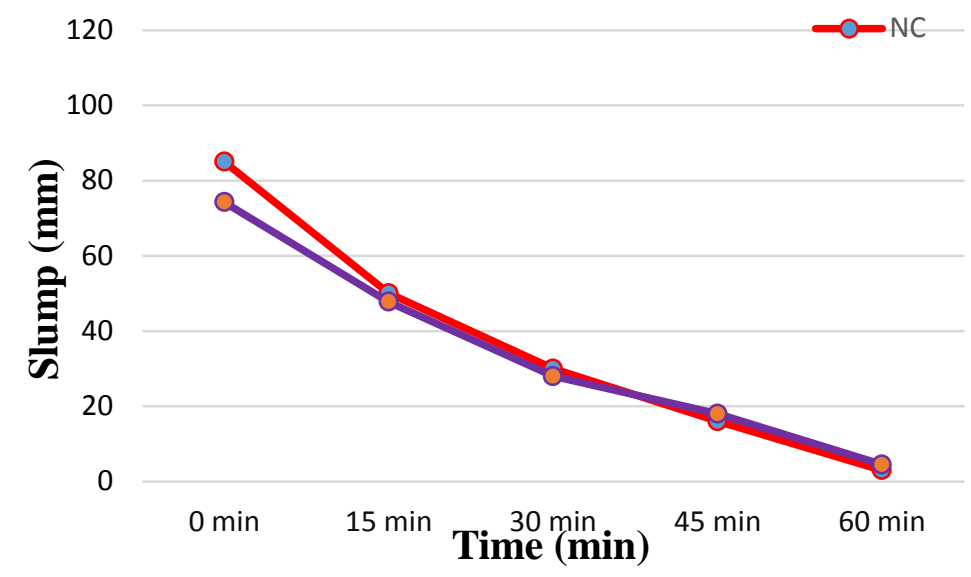

Fig.4: Slump loss- Time relation for mixture having cement content $450 \mathrm{~kg} / \mathrm{m}^{3}$

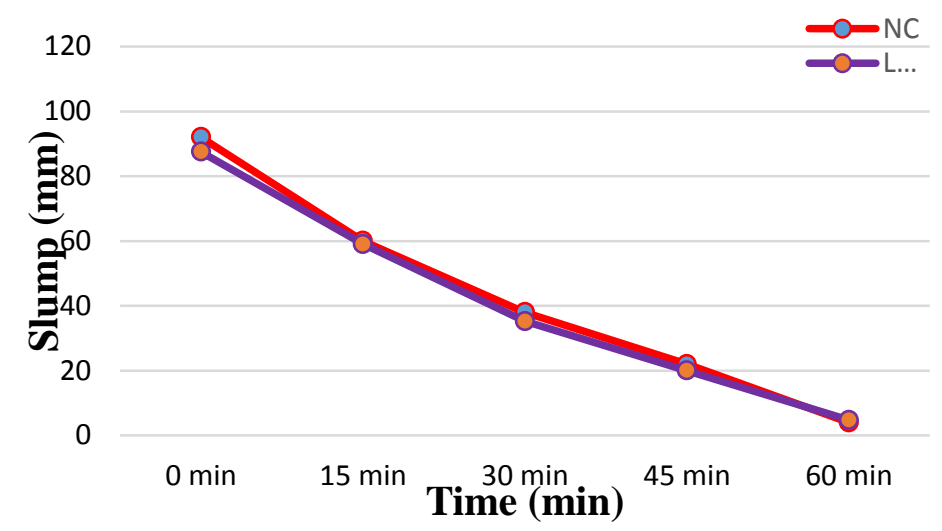

Fig.5: Slump loss- Time relation for mixture having cement content $400 \mathrm{~kg} / \mathrm{m}^{3}$ 


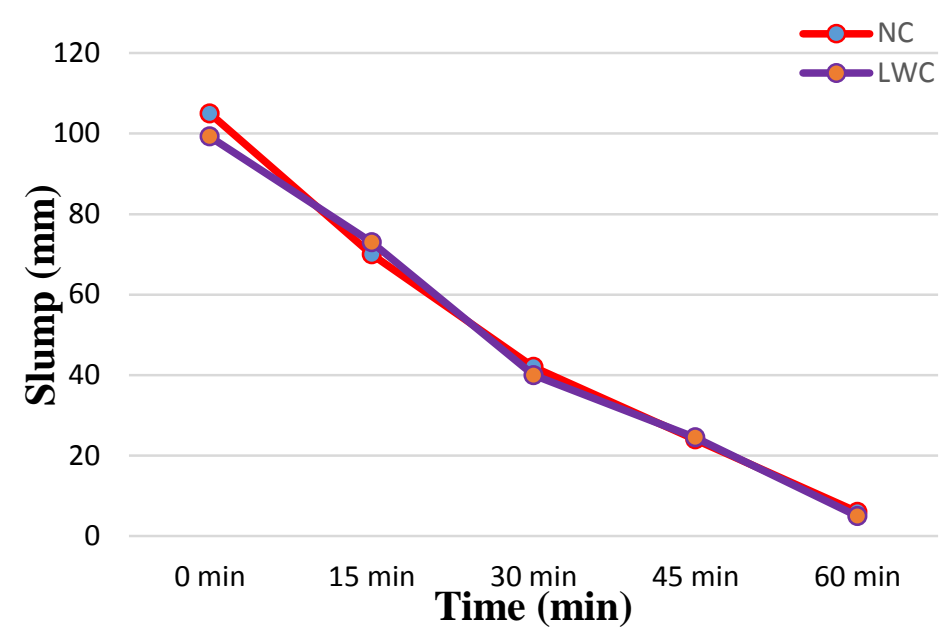

Fig.6: Slump loss- Time relation for mixture having cement content $350 \mathrm{~kg} / \mathrm{m}^{3}$

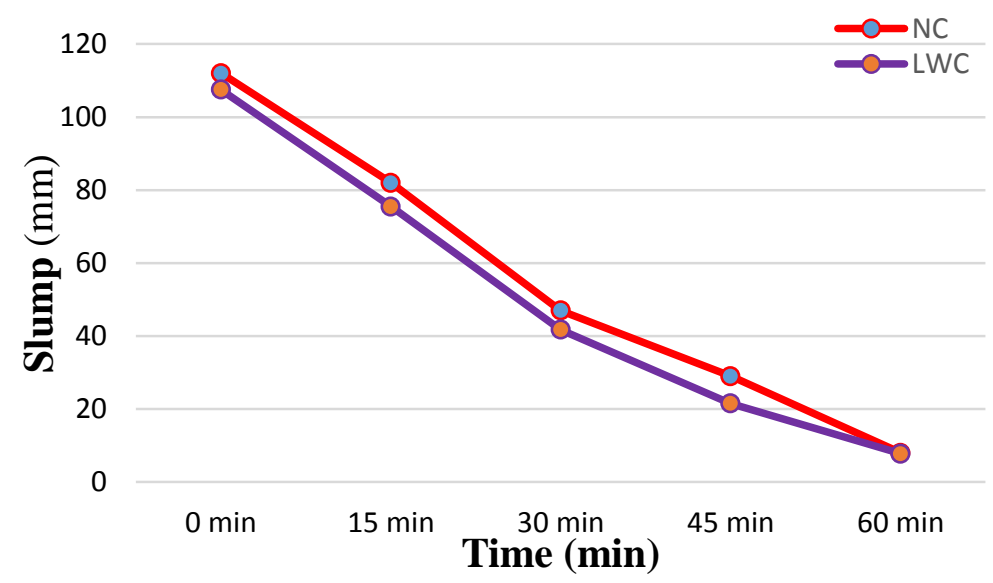

Fig.7: Slump loss- Time relation for mixture having cement content $300 \mathrm{~kg} / \mathrm{m}^{3}$



Fig.8: Slump loss- Time relation for mixture having cement content $250 \mathrm{~kg} / \mathrm{m}^{3}$ 


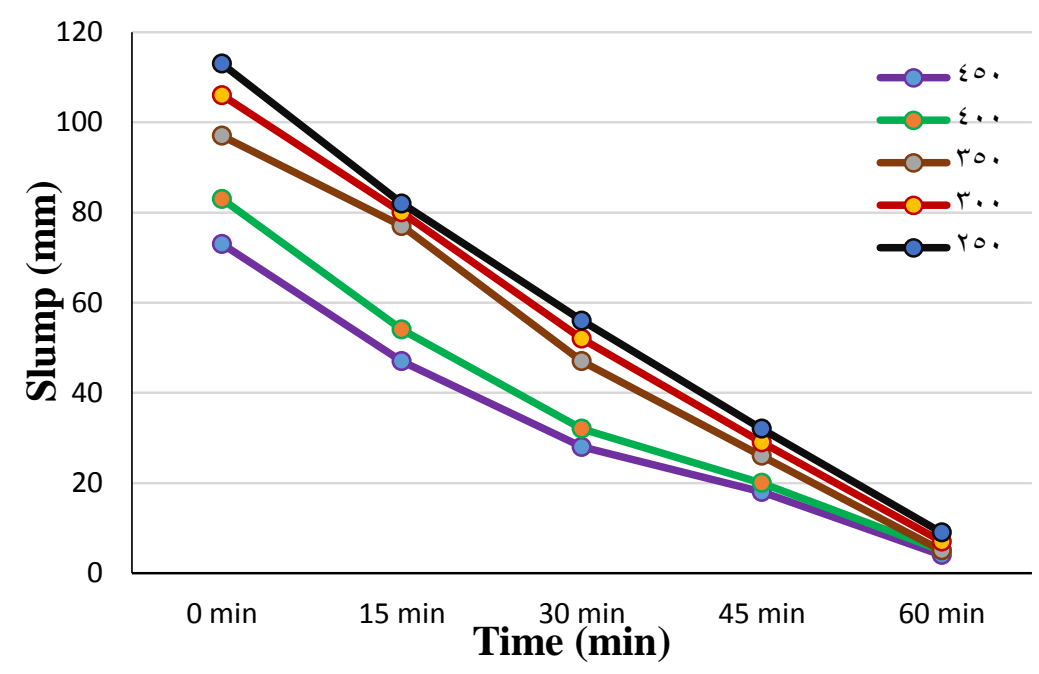

Fig.9: Slump loss- Time relation for $\mathrm{LWC}$ mixture having different cement content

\subsubsection{Compaction factor}

Concrete compaction factor was used to evaluate the workability of fresh concrete.The compaction factor for lightweight concrete reduced by 5\% compared with that for the normal concrete as shown in Fig.10. The mineral admixtures increased the compaction factor for the lightweight concrete.

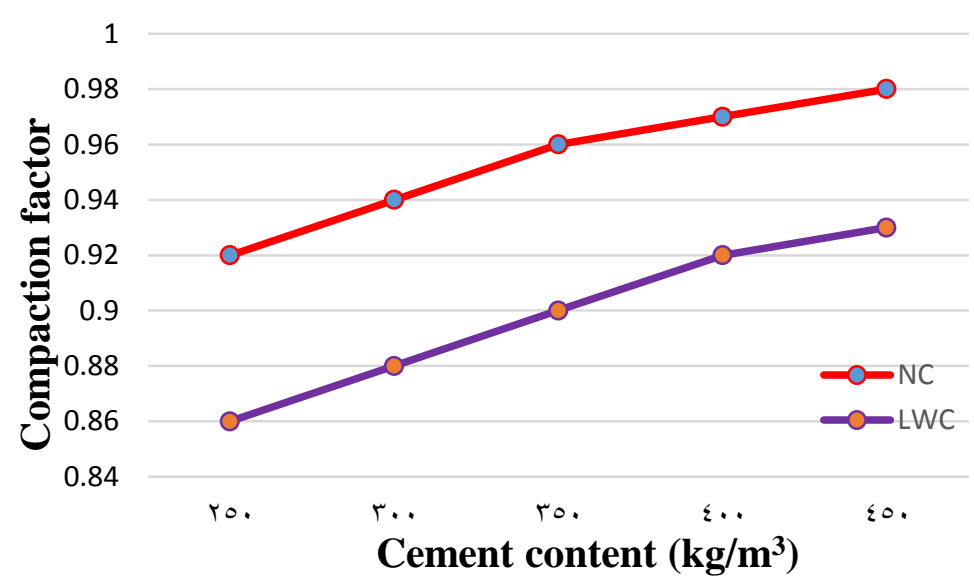

Fig.10: Comparison between compaction factor of $\mathrm{NC}$ and that of $\mathrm{LWC}$ mixtures

\subsection{Hardened Characteristics of lightweight concrete}

\subsubsection{Compressive Strength}

Compressive strength is surely one of the most significant mechanical characteristic of concrete quality. The mode of failure according to the compressive strength test is shown in Fig.11. For Mixtures of cement content is $450 \mathrm{~kg} / \mathrm{m}^{3}$ and w/c ratio is 0.3 , LWCNS2.5 has attained the objective of this paper that produced a structurally 
lightweight concrete. LWCFA, LWCSF are approximately the same manner in the hardened properties. $\mathrm{LWCO}$ is $78 \%$ of the compressive strength of $\mathrm{NCO}$ as shown in Fig.12. Decreasing of cement content and increasing of w/c ratio, the compressive strength is reduced for all mixtures as shown in Fig.13, Fig.14, Fig.15, and Fig.16. Generally, the compressive strength for the plain mixture of lightweight concrete is between $79 \%$ and $82 \%$ of the normal concrete compressive strength. The lightweight concrete with the fly ash of $7.5 \%$ and $15 \%$ improving the compressive strength with $10.9 \%$ and $12.6 \%$, respectively. However, the lightweight concrete with the Nano silica of $2 \%$ and $2.5 \%$ improved the compressive strength with $19.5 \%$ and $23.2 \%$, respectively. Also, the lightweight concrete with the silica fume of $7.5 \%$ and $15 \%$ improved the compressive strength with $11.1 \%$ and $13.3 \%$, respectively. It was observed that the effect of Nano silica on the compressive strength was superior than the using of the others admixtures.
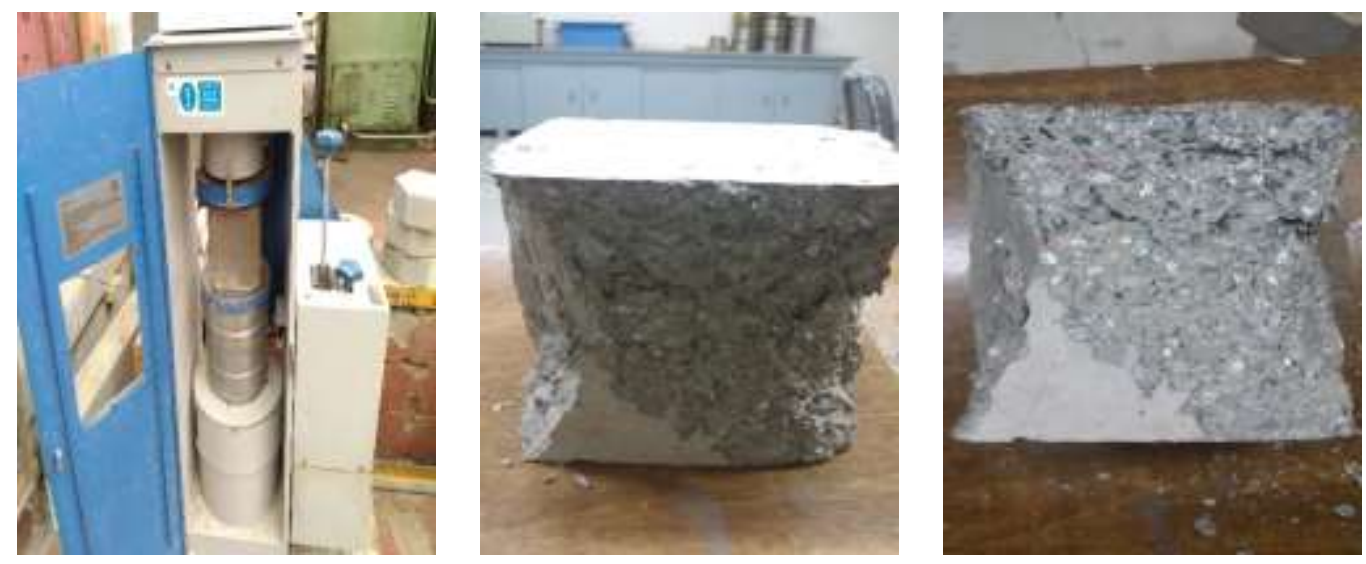

Fig.11: Failure Mode



Fig.12: Compressive strength - Time relationship for LWC or NC or both for mixtures having cement content $450 \mathrm{~kg} / \mathrm{m}^{3}$ 


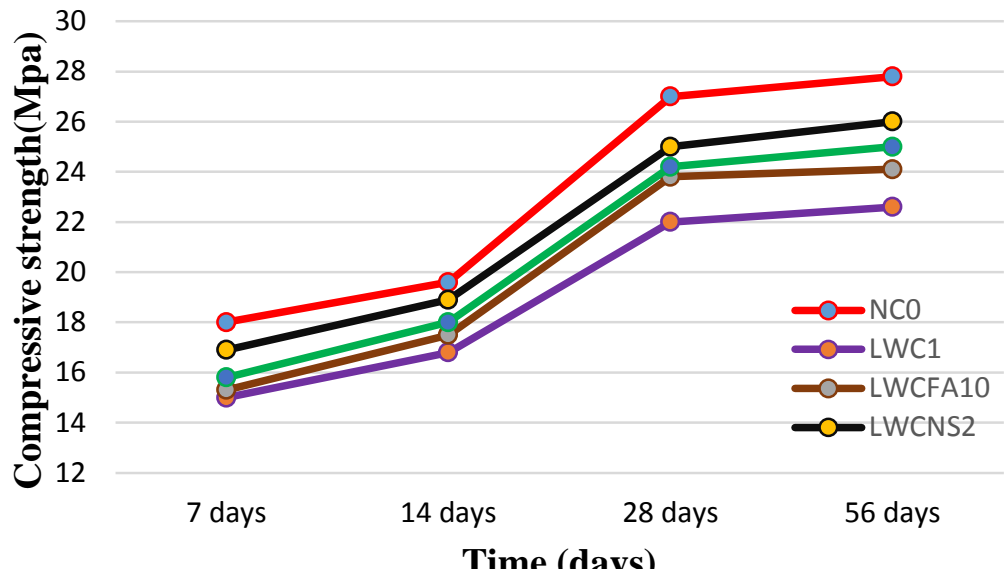

Fig.13: Compressive strength - Time relationship for LWC or NC or both for mixtures having cement content $400 \mathrm{~kg} / \mathrm{m}^{3}$

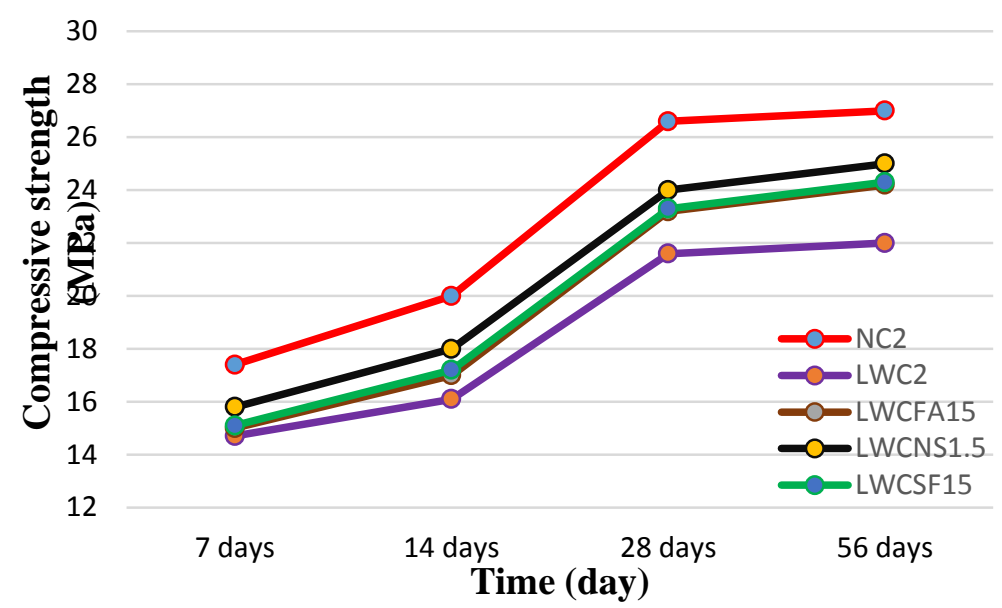

Fig.14: Compressive strength - Time relationship for LWC or NC or both for mixtures having cement content $350 \mathrm{~kg} / \mathrm{m}^{3}$

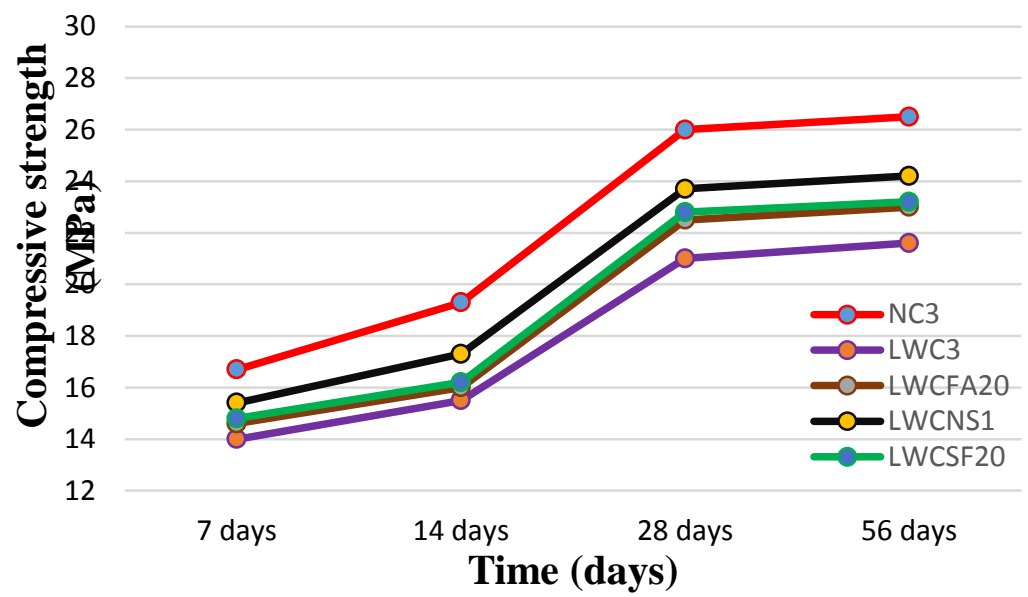

Fig.15: Compressive strength - Time relationship for LWC or NC or both for mixtures having cement content $300 \mathrm{~kg} / \mathrm{m}^{3}$ 




Fig.16: Compressive strength - Time relationship for LWC or NC or both for mixtures having cement content $250 \mathrm{~kg} / \mathrm{m} 3$

\section{CONCLUSION}

From the results of the experimental investigation of different LWC and NC concrete mixtures it can be concluded that:

1. Achieving lightweight concrete using crushed glass as coarse aggregate with nano silica by a ratio of $2.5 \%$ can be used in structure elements.

2. There are similar behavior in the slump loss for NC and LWC concrete

3. For lightweight concrete cement content and w/c ratio are the most effective factors for enhancing properties in the fresh state, but mineral admixtures are the most effective factors for improving the hardened properties.

4. The compaction factor for the lightweight concrete decreased by $3.75 \%$ compared with the compaction factor for the normal concrete.

5. Using Nano silica of $2 \%$ and $2.5 \%$ can enhance the compressive strength for LWC with $19.5 \%$ and $23.2 \%$ and can achieve early age strenght.

6. Using Fly ash or silica fume did the same bahviour in the hardened state in the compressive strength and the tensile strength.

7. The compressive strength for the plain mixtures of lightweight concrete is between $79 \%$ and $82 \%$ of the normal concrete compressive strength.

\section{REFERENCES}

1. ACI 213R-14, Guide for Structural Lightweight Aggregate Concrete, Reported by ACI Committee 213, (2014).

2. ACI (American Concrete Institute) "ACI 211.2 Standard Practice for Selecting Proportions of Structural Lightweight Concrete", ACI, Detroit, (2009).

3. ACI 209.2R-08. Guide for modeling and calculating shrinkage and creep in hardened concrete. American Concrete Institute, (2008).

4. Topc ${ }_{s}$ IB., and Uygunog lu. "Effect of aggregate type on properties of hardened self-consolidating lightweight concrete (SCLC)". Construction and Building Materials, 24, 1286-1295, (2010). 
5. ASTM C330-5, Standard Specification for Lightweight Aggregates for Structural Concrete, ASTM International, (2002).

6. M.A.Hadianfard, S.Jafari. "Prediction of the lightweight aggregate concrete compressive strength using ultrasonic pulse velocity test through gene expression programming", Int. J. Sci. Technol. Civ. Eng. Trans, (2015).

7. Cui HZ, Lo Tommy Yiu. "Effect of lightweight aggregates on the mechanical properties and brittleness of lightweight aggregate concrete". Construction and Building Materials 35, 149-158, (2012).

8. ACI-130-A Materials for Concrete, , Reported by ACI Committee 211, (2007).

9. M.J.Shannag. "Characteristics of lightweight concrete containing mineral admixtures", Construction and Building Materials 25, 568-662, (2011).

10. Harun Tanyildizi. "Variance analysis of crack characteristics of structural lightweight concrete containing silica fume exposed to high temperature" Construction and Building Materials 49, 1154-1159, (2013).

11. Nochaiya T, Wongkeo W, Chaipanich A. "Utilization of fly ash with silica fume and properties of Portland cement-fly, ash-silica, fume concrete". Fuel 893, 768-774, (2010).

12. Zhang MH, Islam J. "Use of Nano-silica to reduce setting time and increase early strength of concretes with high volumes of fly ash or slag". Construction and Building Materials 29, 573-580, (2012).

13. Bastami Morteza, Baghbadrani Mazyar, and Farhad Aslani. "Performance of Nano-silica modified high strength concrete at elevated temperatures, Construction and Building Materials, 68, 402-408, (2014).

14. Egyptian Standard Specifications "Standard Test Method for Concrete", no $1658 / 2008$. 